\title{
The effect of waste water treatment on river metal concentrations: removal or enrichment?
}

\author{
Johannes Teuchies $\cdot$ Lieven Bervoets $\cdot$ Tom J. S. Cox • \\ Patrick Meire • Eric de Deckere
}

Received: 19 July 2010 /Accepted: 17 November 2010 /Published online: 1 December 2010

(C) The Author(s) 2010. This article is published with open access at Springerlink.com.

\begin{abstract}
Purpose Discharge of untreated domestic and industrial waste in many European rivers resulted in low oxygen concentrations and contamination with trace metals, often concentrated in sediments. Under these anoxic conditions, the formation of insoluble metal sulfides is known to reduce metal availability. Nowadays, implementation of waste water treatment plants results in increasing surface water oxygen concentrations. Under these conditions, sediments can be turned from a trace metal sink into a trace metal source.

Materials and methods In an ex situ experiment with metal contaminated sediment, we investigated the effect of surface water aeration on sediment metal sulfide (acid volatile sulfides (AVS)) concentrations and sediment metal release to the surface water. These results were compared with long-term field data, where surface water oxygen and metal concentrations, before and after the implementation of a waste water treatment plant, were compared.
\end{abstract}

Responsible editor: Michael Kersten

J. Teuchies $(\bowtie) \cdot$ T. J. S. Cox • P. Meire • E. de Deckere

Department of Biology, Ecosystem Management Research Group,

University of Antwerp,

Universiteitsplein $1 \mathrm{C}$,

2610, Wilrijk, Belgium

e-mail: johannes.teuchies@ua.ac.be

L. Bervoets

Department of Biology, Ecophysiology,

Biochemistry and Toxicology Group, University of Antwerp,

Groenenborgerlaan 171,

2020, Antwerp, Belgium

T. J. S. Cox

Netherlands Institute of Ecology (NIOO-KNAW),

Centre for Estuarine and Marine Ecology,

PO Box 140, 4400 AC, Yerseke, The Netherlands
Results and discussion Aeration of surface water in the experimental setup resulted in a decrease of sediment AVS concentrations due to sulfide oxidation. Metals, known to precipitate with these sulfides, became more mobile and increasing dissolved metal (arsenic (As), cadmium (Cd), copper $(\mathrm{Cu})$ ) concentrations in the surface water were observed. Contrary to $\mathrm{As}, \mathrm{Cd}$, or $\mathrm{Cu}$, manganese (Mn) surface water concentrations decreased in the aerated treatment. Mn ions will precipitate and accumulate in the sediment as Mn oxides under the oxic conditions. Field data, however, demonstrated a decrease of all total metal surface water concentrations with increasing oxygen concentrations following the implementation of the waste water treatment plant.

Conclusions The gradual decrease in surface water metal concentrations in the river before the treatment started and the removal of metals in the waste water treatment process could not be countered by an increase in metal flux from the sediment as observed in the experiment.

Keywords Acid volatile sulfides (AVS) - Metal availability · Oxidation · Redox chemistry · Sediments . Simultaneously extracted metals (SEM)

\section{Introduction}

Metal contamination is one of the most complex issues of today's contamination problems. Widespread uses of metals, the legacies of past contamination, and new technologies continue to pose important ecological risks for aquatic environments across the earth (Luoma and Rainbow 2008). In the course of the last decades, a gradual decrease of the surface water metal concentrations has been observed in Europe. Nevertheless, metal contaminated river 
sediments can still constitute an ecological threat. Since trace metals show a high affinity for organic and inorganic particles, these contaminants are often historically concentrated in the sediments (Du Laing et al. 2009; Hart 1982; Regnier and Wollast 1993). The formation of insoluble metal sulfides is found to play a major role in reducing sediment metal availability and transfer to the surface water under anoxic conditions (Di Toro et al. 1990, 1992). The ratio of acid extracted sulfides (acid volatile sulfides (AVS)) and simultaneously extracted metals (SEM) is proposed as a predictor for availability of some divalent metals (cadmium $(\mathrm{Cd})$, copper $(\mathrm{Cu})$, lead $(\mathrm{Pb})$, nickel $(\mathrm{Ni})$, and zinc (Zn)) (Allen et al. 1993; Di Toro et al. 1992).

Anthropogenic activities (dredging, waste water treatment) or natural induced changes (seasonality, bioturbation, storms) might result in an increase of oxygen levels in both surface water and sediment (Peterson et al. 1996; Zhuang et al. 1994). Under these conditions, metal sulfides may be oxidized and sediments can be turned from a trace metal sink into a trace metal source (Maddock et al. 2007; Petersen et al. 1997). Resuspension of anoxic sediments in oxic surface water caused by dredging and dumping or natural events can enhance this process and can result in a larger dissolved metal flux to the surface water and increased metal availability (Eggleton and Thomas 2004; Hedge et al. 2009).

The aim of this study was to investigate the effect of aeration and resuspension of sediments on the mobility of metals to the water column. Therefore, a controlled experiment was conducted, and results were compared with longterm data from the river Zenne as test case. The river Zenne flows through Brussels, Belgium, and the basin is situated in one of the most densely populated areas of Europe. Untreated domestic and industrial waste water has been discharged in the river for decades, resulting in severe contamination of water and sediment with micro pollutants such as trace metals and in a decreased oxygen level in the surface waters. In the long-term experiment with ex situ river Zenne sediment cores, we investigated the effect of surface water aeration on sediment SEM/AVS concentrations and sediment metal release to the surface water. These results were compared with long-term field data, where river Zenne surface water oxygen, metal, and suspended solid concentrations before and after the implementation of the waste water treatment plant in March 2007 were compared.

\section{Material and methods}

\subsection{Sampling site}

Sediment and water have been sampled May 2006, downstream of Brussels near to Weerde $\left(50^{\circ} 58^{\prime} 07.96^{\prime \prime} \mathrm{N}\right.$, $4^{\circ} 28^{\prime} 47.27^{\prime \prime}$ E). First, the water was sampled and stored in big barrels for 3 days at $4^{\circ} \mathrm{C}$ to enable settling of suspended material. One week later, the sediment was sampled at the same location with an Eckman grab sampler. The sediment $(9 \%<2 \mu \mathrm{m}, 2 \mu \mathrm{m}<44 \%<63 \mu \mathrm{m})$ at the site contained a high concentration of metals (As, $18 \mu \mathrm{g} \mathrm{g}^{-1}$ dry mass; $\mathrm{Cd}$, $4.5 \mu \mathrm{g} \mathrm{g}^{-1}$ dry mass; $\mathrm{Cr}, 65 \mu \mathrm{g} \mathrm{g}^{-1}$ dry mass; $\mathrm{Cu}, 194 \mu \mathrm{g}$ $\mathrm{g}^{-1}$ dry mass; $\mathrm{Hg}, 3.0 \mu \mathrm{g} \mathrm{g}^{-1}$ dry mass; Ni, $43 \mu \mathrm{g} \mathrm{g}^{-1}$ dry mass; Pb, $398 \mu \mathrm{g} \mathrm{g}^{-1}$ dry mass; Zn, $970 \mu \mathrm{g} \mathrm{g}^{-1}$ dry mass).

\subsection{Experimental setup}

In order to approach the natural situation, this experiment was executed in sediment cores with a layer of surface water, in a climate chamber with constant temperature $\left(20^{\circ} \mathrm{C}\right)$. First, the water was added to 15 individual PVC cores (diameter, $24 \mathrm{~cm}$; height, $40 \mathrm{~cm}$ ). Immediately after sampling, sediments were homogenized, distributed over the cores with water and given $12 \mathrm{~h}$ to settle before the start of the experiment. This resulted in a sediment layer of $20 \mathrm{~cm}$ and a surficial water layer of $15 \mathrm{~cm}$. Surface water levels were replenished regularly with demineralized water in order to maintain the initial level.

Rhizons (pore water sampler, Eijkelkamp) were inserted horizontally through holes in each core in order to sample pore water (2.5-cm sediment depth). An air pump was placed in the surface water of each core. Differences in air pump flow rate (none, low, and high) resulted in different oxygen concentrations and suspended solid load: three treatments with five replicates. The three different treatments investigated consisted of (1) anoxic: a non aerated treatment with low oxygen and suspended solid concentrations, (2) oxic-clear: a low aerated treatment with high oxygen and low suspended solid concentrations, and (3) oxic-turbid: a high aerated treatment with high oxygen and resuspension resulting in high suspended solid concentrations (Fig. 1).

\subsection{Sampling}

Water and sediment samples were taken from the batch tests after 1.5 years of treatment. Previous to sampling, surface water was gently mixed and basic water characteristics were measured (oxygen, suspended solid concentration, $\mathrm{pH}$, and conductivity). Surface water was sampled with $10-\mathrm{mL}$ syringes. The upper $5 \mathrm{~cm}$ of the sediment was sampled with a small $(1 \mathrm{~cm}$ in diameter) sediment corer. In each core, five sediment samples were taken randomly and mixed. In order to extract pore water from the sediment, a vacuum pump was connected to the Rhizon samplers.

\subsection{Analyses}

Oxygen concentrations, $\mathrm{pH}$, and conductivity were measured using a WTW Oxi 315i and WTW pH/Cond 340i set. 
Fig. 1 Mean oxygen and suspended solid concentrations with the standard error $(n=5)$ for the three different treatments in the core experiment

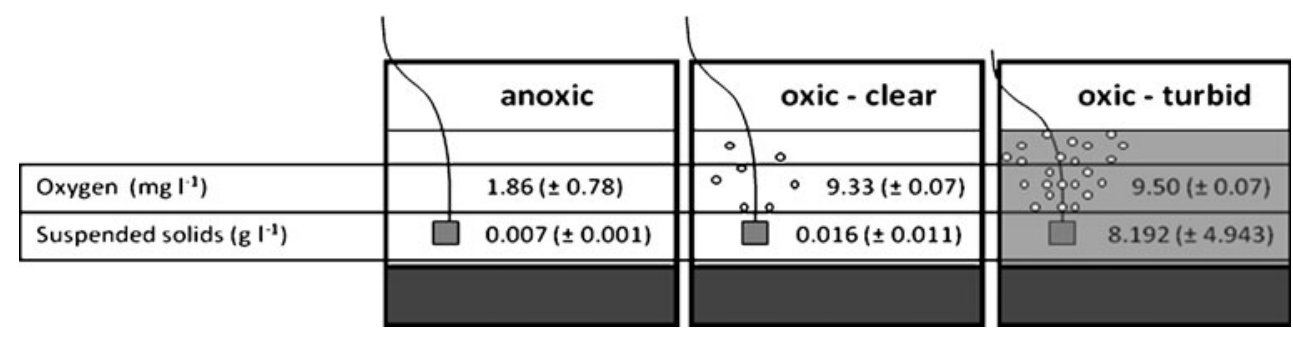

Surface water suspended solid (ss) concentrations were measured by filtering from $0.05 \mathrm{~L}$ up to $1 \mathrm{~L}$, depending on the ss concentration, over a preweighed filter (Wathman, glass fiber, particle retention $1.2 \mu \mathrm{m})$. Filters and blanks were dried at $105^{\circ} \mathrm{C}$ and weighed again. Total metal concentrations (arsenic (As), $\mathrm{Cd}$, chromium $(\mathrm{Cr}), \mathrm{Cu}$, manganese $(\mathrm{Mn})$, and $\mathrm{Pb}$ ) were measured in both pore and surface water of the batch tests. Since Rhizon water samplers with standard $0.1-\mu \mathrm{m}$ pores are used to sample pore water, this water phase can be assumed dissolved. Water samples for total metal concentrations $(10 \mathrm{~mL})$ were acidified with $100 \mu \mathrm{L}$ nitric acid $\left(\mathrm{HNO}_{3}\right.$ 69\% Normapur Trace Analysis $\mathrm{Cd} \mathrm{Hg} \mathrm{Pb)} \mathrm{and} \mathrm{then} \mathrm{filtered} \mathrm{(cellulose} \mathrm{ester,}$ $0.45-\mu \mathrm{m}$ pore diameter). Water samples for dissolved metal concentrations measured in the surface water of the batch tests were first filtered and then acidified. Water metal concentrations were determined using an inductively coupled plasma mass spectrometer (ICP-MS, Varian UltraMass 700), with Germanium (Ge) as internal standard.

In the batch tests, sediment AVS, SEM $(\mathrm{Cd}, \mathrm{Cu}, \mathrm{Ni}, \mathrm{Pb}$, and $\mathrm{Zn}$ ), and total metal concentrations (As, $\mathrm{Cd}, \mathrm{Cr}, \mathrm{Cu}$, and $\mathrm{Pb}$ ) were measured. Immediately after sampling, a part of the wet sediment is weighed and oven dried $\left(40^{\circ} \mathrm{C}\right)$. The rest of the sediment is weighed and immediately used for AVS and SEM determination following the purge-and-trap method of Allen et al. (1993); wet sediment was stirred for $2 \mathrm{~h}$ with hydrochloric acid $(\mathrm{HCl}, 37 \%$, Normapur) to dissociate metals and sulfides. The $\mathrm{H}_{2} \mathrm{~S}$ gas formed by this reaction was lead through a $\mathrm{NaOH}$ solution by the constant $\mathrm{N}_{2}$ flow. The $\mathrm{S}^{-}$ions were measured photospectrometically in the solution in order to determine the AVS concentration. In order to determine SEM concentrations, metal concentrations in the sediment-acid mixture were measured after filtration using ICP type radial plasma iris/charge injection device (CID) (Thermo).

Dried sediments are grinded and used for determination of total metal concentration after "hot block digestion." For digestion, $5 \mathrm{~mL}$ nitric acid $\left(\mathrm{HNO}_{3}\right.$ 69\% Normapur Trace Analysis $\mathrm{Cd} \mathrm{Hg} \mathrm{Pb})$ and $5 \mathrm{~mL}$ of hydrogen peroxide $\left(\mathrm{H}_{2} \mathrm{O}_{2}\right.$ $27 \%$ for electrical purpose) are added to $0.2 \mathrm{~g}$ of soil. This mixture is heated up to $100^{\circ} \mathrm{C}$ for $30 \mathrm{~min}$, cooled overnight, and again heated at $150^{\circ} \mathrm{C}$ during $60 \mathrm{~min}$. Sediment metal concentrations were determined using ICP type radial plasma iris/CID (Thermo). Blanks and certified reference material for sediment (Institute for Reference Materials and
Measurements (IRMM), BCR ${ }^{\circledR}$ no. 320, river sediment) and water (IRMM, BCR ${ }^{\circledR}$ no. 610, groundwater) were included in all series of metal analysis in order to verify the analyzed procedure.

\subsection{Field data}

The findings from the experiment were compared with field data from the river Zenne itself. The $1,164 \mathrm{~km}^{2}$ river basin covers one of the most densely populated areas of Europe. With its $103 \mathrm{~km}$ length, the Zenne passes through Brussels, Belgium before discharging itself into the Rupel and subsequently into the Scheldt estuary. For decades, waste water was discharged untreated into the river with high pollution and low oxygen concentrations as a consequence. In March 2007, a waste water treatment plant with a capacity of 1,100,000 inhabitant's equivalent became operative, resulting in an instant increase of the water quality. Surface water data from before and after the treatment started were investigated. All the long-term surface water data from the Zenne were collected from the database of the Flemish Environment Agency (www.vmm.be/geoview). Measuring and sampling frequency varied depending on the parameter and sampling location.

\subsection{Statistical analysis}

The statistical analysis was carried out using the SAS statistical package (The SAS ${ }^{\circledR}$ System, SAS institute Inc., Cary, NC, USA). The significance of differences between treatments was tested with an ANOVA. The Tuckey a posteriori test was used to evaluate the differences mutually.

\section{Results}

\subsection{Experimental results}

The anoxic treatment had low oxygen $\left(1.86 \mathrm{mg} \mathrm{L}^{-1}\right)$ and low suspended solid $\left(0.004 \mathrm{~g} \mathrm{~L}^{-1}\right)$ concentrations. The oxic-clear treatment had high oxygen $\left(9.33 \mathrm{mg} \mathrm{L}^{-1}\right)$ and low suspended solid concentrations $\left(0.014 \mathrm{~g} \mathrm{~L}^{-1}\right)$. The oxic-turbid treatment had high oxygen $\left(9.50 \mathrm{mg} \mathrm{L} \mathrm{L}^{-1}\right)$ and high suspended solid $\left(8.165 \mathrm{~g} \mathrm{~L}^{-1}\right)$ concentrations (see Fig. 1). Total metal concentrations in the experimental 
sediment for all treatments were $8.05 \pm 2.15 \mu \mathrm{g} \mathrm{g} \mathrm{g}^{-1}$ dry mass (As), $6.09 \pm 0.31 \mu \mathrm{g} \mathrm{g}{ }^{-1}$ dry mass (Cd), 213.18 $10.20 \mu \mathrm{g} \mathrm{g}^{-1}$ dry mass $(\mathrm{Cu}), 529.14 \pm 25.64 \mu \mathrm{g} \mathrm{g}^{-1}$ dry mass $(\mathrm{Pb})$, and $240.30 \pm 15.51 \mu \mathrm{g} \mathrm{g}^{-1}$ dry mass $(\mathrm{Mn})$. No significant differences between sediment total metals in the upper $5 \mathrm{~cm}$ were found among treatments. The 1.5-year period of surface water aeration resulted in significant lower sediment AVS concentrations in the oxic-clear $\left(1.74 \mathrm{mmol} \mathrm{kg}^{-1}, p<0.001\right)$ and the oxic-turbid $(0.59 \mathrm{mmol}$ $\left.\mathrm{kg}^{-1}, p<0.001\right)$ treatments compared to the anoxic treatment (35.51 mmol kg-1) (Fig. 2). Anoxic treatment SEM concentrations were significantly lower compared to the oxic-clear $(p=0.0148)$ and the oxic-turbid $(p=0.0049)$ treatments (see Fig. 2). The SEM/AVS ratio which is lower than $1(0.75 \pm 0.17)$ in the anoxic treatment indicated the presence of an excess of sulfides which can precipitate with trace metals in the sediment. Higher SEM/AVS ratios for the oxic-clear $(29.50 \pm 12.20)$ and oxic-turbid $(73.26 \pm$ 17.23) treatments can indicate a higher metal availability in the sediment.

A significant increase in dissolved metal concentrations in the surface water of the experimental cores with increasing aeration level was found for As $(p=0.0010)$, $\mathrm{Cd}(p=0.0003)$, and $\mathrm{Cu}(p=0.0017)$ (Fig. 3). The opposite trend, decreasing dissolved metal concentrations with increasing aeration level, was found for $\mathrm{Mn}(p=0.0241)$ (see Fig. 3).

Surface water total metal concentrations are from 54 $(\mathrm{Mn})$ up to $566(\mathrm{Cd})$ times higher in the oxic-turbid treatment compared to the anoxic treatment (Table 1). Despite these high values, differences in concentrations between treatments were not significant $(p>0.05$ for all metals). The variation in total metal concentrations within the treatments, especially in the oxic-turbid, was very high. For example, total $\mathrm{Pb}$ concentrations in the oxic-turbid treatment surface water varied from 131 to $12,930 \mu \mathrm{g} \mathrm{L} \mathrm{L}^{-1}$ between cores. Related to these results, also suspended

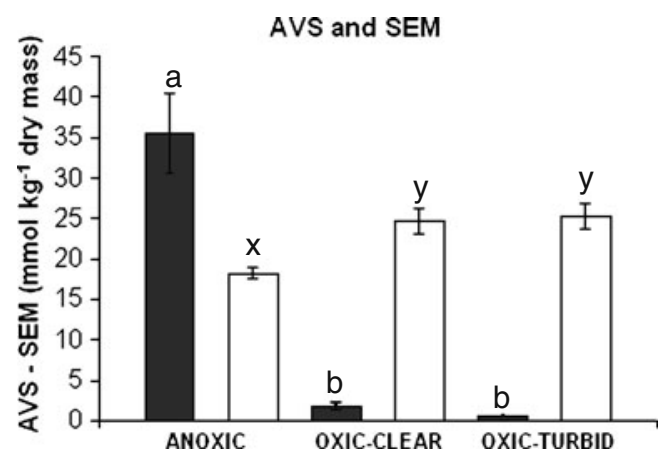

Fig. 2 AVS (dark) and SEM (light) concentrations in the experiment top $5 \mathrm{~cm}$ sediments after 1.5 years of treatment. Mean values $(n=5)$ with standard error. Both variables expressed on the same axes with same units solid concentrations showed a very high variation within treatments. Suspended solid concentrations in the surface water of the oxic-turbid treatment varied from 0.03 to $22.23 \mathrm{mg} \mathrm{L}^{-1}$. Consequently, a positive, highly significant correlation between surface water total metal and suspended solid concentration in the experiment was found ( $p<0.0001$ for all metals).

A significant $(p<0.0001)$ increase in $\mathrm{pH}$ with increasing aeration level was observed. The $\mathrm{pH}$ values rose from $6.70 \pm 0.03$ in the anoxic treatment to $7.05 \pm 0.01$ in the oxicclear treatment and again to $7.39 \pm 0.10$ in the oxic-turbid treatment. Significant $(p=0.0025)$ differences in surface water conductivity between the anoxic treatment $(451 \pm$ $\left.141 \mu \mathrm{s} \mathrm{cm}^{-1}\right)$, the oxic-clear $\left(1,996 \pm 164 \mu \mathrm{s} \mathrm{cm}^{-1}\right)$, and the oxic-turbid treatment $\left(1,451 \pm 325 \mu \mathrm{s} \mathrm{cm}^{-1}\right)$ were observed.

No significant differences between pore water concentrations in the three different treatments were found $(p>0.05$ for all metals). A high variability between samples from one treatment can be observed (Fig. 4).

\subsection{Field results}

Waste water treatment resulted in an instant increase in Zenne surface water oxygen concentrations from an average of $1.96 \pm 0.16 \mathrm{mg} \mathrm{L}^{-1}$ in the 18 years before purification to $6.30 \pm 0.20 \mathrm{mg} \mathrm{L}^{-1}$ in the 3 years after purification (Fig. 5). Especially the periods with low oxygen concentrations during summer, observed before purification started, disappeared. The suspended solid concentration decreased with purification (Fig. 6).

The total $\mathrm{Cu}$ and $\mathrm{Pb}$ concentrations in the Zenne surface water were generally decreasing after 1990 (Fig. 7). No clear long-term trend was observed for total $\mathrm{As}, \mathrm{Cd}$, and Mn concentrations in the Zenne surface water (see Fig. 7). From waste water purification in 2007 onward, a noticeable decrease in most examined total metal $(\mathrm{Cd}, \mathrm{Cu}, \mathrm{Pb}, \mathrm{Mn})$ concentrations was observed (see Fig. 7). Similarly as in the experiment, significant positive correlations between the total metal concentrations and the suspended solids in the Zenne surface water were found $(\mathrm{Cd}(p=0.0098), \mathrm{Cu}$ $(p=0.0026), \mathrm{Pb}(p=0.0116), \mathrm{Mn}(p=00256))$. Unfortunately, the data on dissolved metal concentrations in the Zenne surface water were limited. The dissolved concentrations were measured for $\mathrm{Mn}$ and $\mathrm{Cu}$, but not enough samples were taken in order to draw clear conclusions on differences before and after waste water treatment (Fig. 8)

\section{Discussion}

Drainage of untreated waste water in the river Zenne caused severe contamination. Sediment metal concentrations were high and exceeded Flemish quality standards (for reuse as 



Fig. 3 Surface water dissolved metal concentrations in the experiment after 1.5 years of treatment. Mean values $(n=5)$ with standard error

soil) (QS) 11 times ( $\mathrm{Zn}), 2$ times (Cu), up to 40 (Cr), and even more than 50 times $(\mathrm{Pb})$ (Flemish Government 1996). Despite these high values, all surface water total metal concentrations besides $\mathrm{Zn}$ dropped below Flemish QS in recent years (Flemish Government 2000).

Additionally, contaminated effluents caused decades of low oxygen concentrations in the surface water of the Zenne. Surface water low oxygen concentrations in the anoxic treatment in the experiment resulted in an excess of sulfides compared to SEM in the sediment. Since sulfides precipitate with some trace metals, a lower availability can be expected under the anoxic conditions (Allen et al. 1993; Di Toro et al. 1990, 1992). Additionally, lower SEM values were observed in the anoxic treatment. During 1.5 years of anaerobic conditions, pyrite may be formed. This strong sulfite-metal combination, which will not be released entirely during the AVS-SEM extraction (Morse 1994), can explain the lower SEM values found in the anoxic treatment sediments. As observed in the Zenne, surface water oxygen concentrations increased promptly after the waste water treatment plant of Brussels was started up. The

Table 1 Surface water total metal concentrations (micrograms per liter) after 1.5 years of treatment

\begin{tabular}{lccc}
\hline & Anoxic & Oxic-clear & Oxic-turbid \\
\hline $\mathrm{As}$ & $4.17( \pm 0.52)$ & $6.86( \pm 0.84)$ & $294.04( \pm 140.41)$ \\
$\mathrm{Cd}$ & $0.12( \pm 0.04)$ & $0.21( \pm 0.03)$ & $66.02( \pm 34.50)$ \\
$\mathrm{Cu}$ & $8.12( \pm 2.51)$ & $11.80( \pm 2.13)$ & $3,200.70( \pm 1,610.48)$ \\
$\mathrm{Pb}$ & $11.04( \pm 4.62)$ & $8.77( \pm 3.75)$ & $5,777.43( \pm 2,771.17)$ \\
$\mathrm{Mn}$ & $71.90( \pm 14.27)$ & $37.27( \pm 21.75)$ & $3,860.70( \pm 2,010.76)$ \\
\hline
\end{tabular}

Data are presented as mean values with standard error experimental results showed that these higher oxygen concentrations can result in a drastic decrease in sediment AVS concentrations. In both oxic treatments, surface water oxygen penetrated the sediment and sulfide precipitates in the top soil layer were oxidized. Higher trace metal availability in sediment and surface water can be a consequence (Hartley and Dickinson 2010; Van den Berg et al. 1998).

Furthermore, metal flux to the overlying water was influenced by surface water aeration in the experiment. An increase of dissolved metals in the surface water (As, $\mathrm{Cd}$, and $\mathrm{Cu}$ ) was observed in the cores which had been subjected to aeration and resuspension. $\mathrm{Cd}$ and $\mathrm{Cu}$ are known to (co)precipitate with sulfides (Di Toro et al. 1992; Morse and Rickard, 2004). Sulfides will be oxidized to sulfate under the aerobic conditions, and (co)precipitated $\mathrm{Cd}$ and $\mathrm{Cu}$ will be released and can diffuse to pore and surface water.

Despite a difference in chemical behavior compared to $\mathrm{Cd}, \mathrm{Cu}$, and $\mathrm{Pb}$, the metalloid As showed the same trend and was enriched in the surface water under the oxic conditions in the experiment as well. Depending on $\mathrm{pH}$ and redox potential (Eh), $\mathrm{As}^{\mathrm{V}}$ or $\mathrm{As}^{\mathrm{III}}$ will be the predominant form (Sharma and Sohn 2009). In the anoxic cores, the more toxic form As ${ }^{\mathrm{III}}$ will dominate (Sharma and Sohn 2009). Comparable with $\mathrm{Cd}$ and $\mathrm{Cu}, \mathrm{As}^{\mathrm{III}}$ can be retained associated with sulfides, predominantly as arsenopyrite, in sulfur-rich sediments, under reduced conditions (Bose and Sharma 2002; Keimowitz et al. 2005; Moore et al. 1988). Oxidation of these As-sulfide precipitates can result in a release of As to pore water and surface water (Keimowitz et al. 2005), explaining the higher dissolved As concentrations in the oxic cores. 


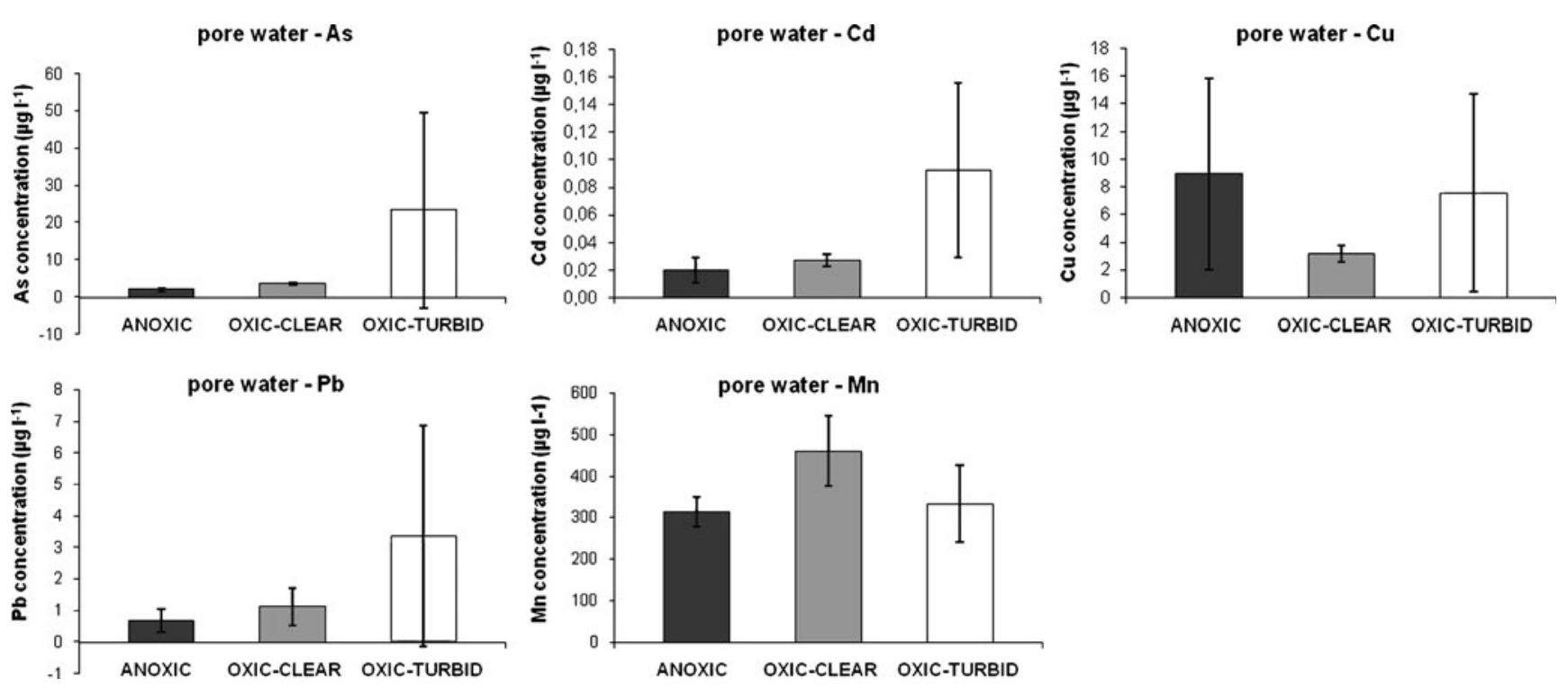

Fig. 4 Pore water metal concentrations on $2.5-\mathrm{cm}$ depth in the experiment sediments after 1.5 year of treatment. Mean values $(n=5)$ with standard error

As observed in the experiment for $\mathrm{Cu}$, metal remobilization can be more pronounced when suspended solid concentrations are high. Metal sulfide precipitates can be transported as suspended solids in the water column. The contact surface between oxic surface water and metal sulfides is larger in suspended solids compared to bottom sediments. High suspended solid concentrations are found in turbid rivers or during short-term resuspension events. Dredging activities, storm events, or bioturbation can cause resuspension of anoxic metal contaminated sediments into oxic surface waters. This can result in a very fast increase in metal availability due to metal sulfide oxidation (Cappuyns et al. 2006; Hedge et al. 2009; Saulnier and Mucci 2000).

Contrary to the other metals, decreasing surface water dissolved Mn concentrations, subsequent to aeration and resuspension, were observed in the experiment. Soluble $\mathrm{Mn}^{\mathrm{II}}$ ions will precipitate and accumulate in the sediment as Mn oxides under the oxic conditions in the aerated cores. $\mathrm{Li}$

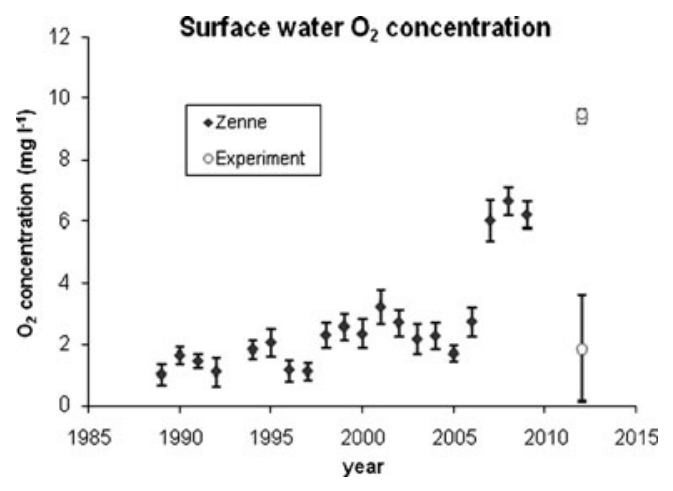

Fig. 5 Zenne (black circle) and experiment (white circle) surface water oxygen concentrations. Zenne concentrations measured weekly at one point in the river. Year mean values with standard errors et al. (2009) found Mn oxides to be the most important component controlling the adsorption of metals in superficial sediments. As concluded by Zhuang et al. (1994), the transfer of sediment bound metals to the surface water as a consequence of sulfide oxidation could be much larger if no other binding phases such as $\mathrm{Mn}$ and $\mathrm{Fe}$ oxides are available. Since dissolved $\mathrm{Cd}, \mathrm{Cu}, \mathrm{Pb}$, and As concentrations increased in both oxic treatments, a higher contribution of sulfide compounds in controlling metal mobility compared to the binding phases under oxic conditions can be assumed under these experimental conditions. In addition, the higher surface water conductivity in both OXIC treatments indicates higher surface water ion concentrations.

In addition to sediments, metals in the surface water can be precipitated with sulfides as well, behaving as suspended solids. Oxic conditions can dissolve these complexes, and the dissolved metal fraction in the surface water can increase

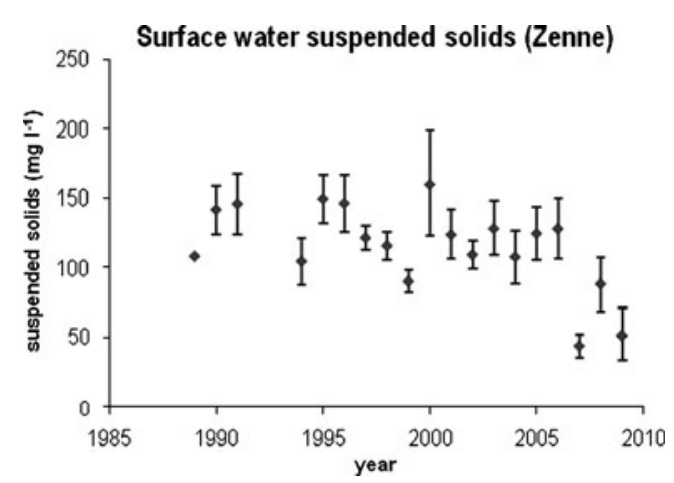

Fig. 6 Zenne surface water suspended solid concentrations measured semi-monthly at one point in the river. Year mean $(n=24)$ values with standard errors 

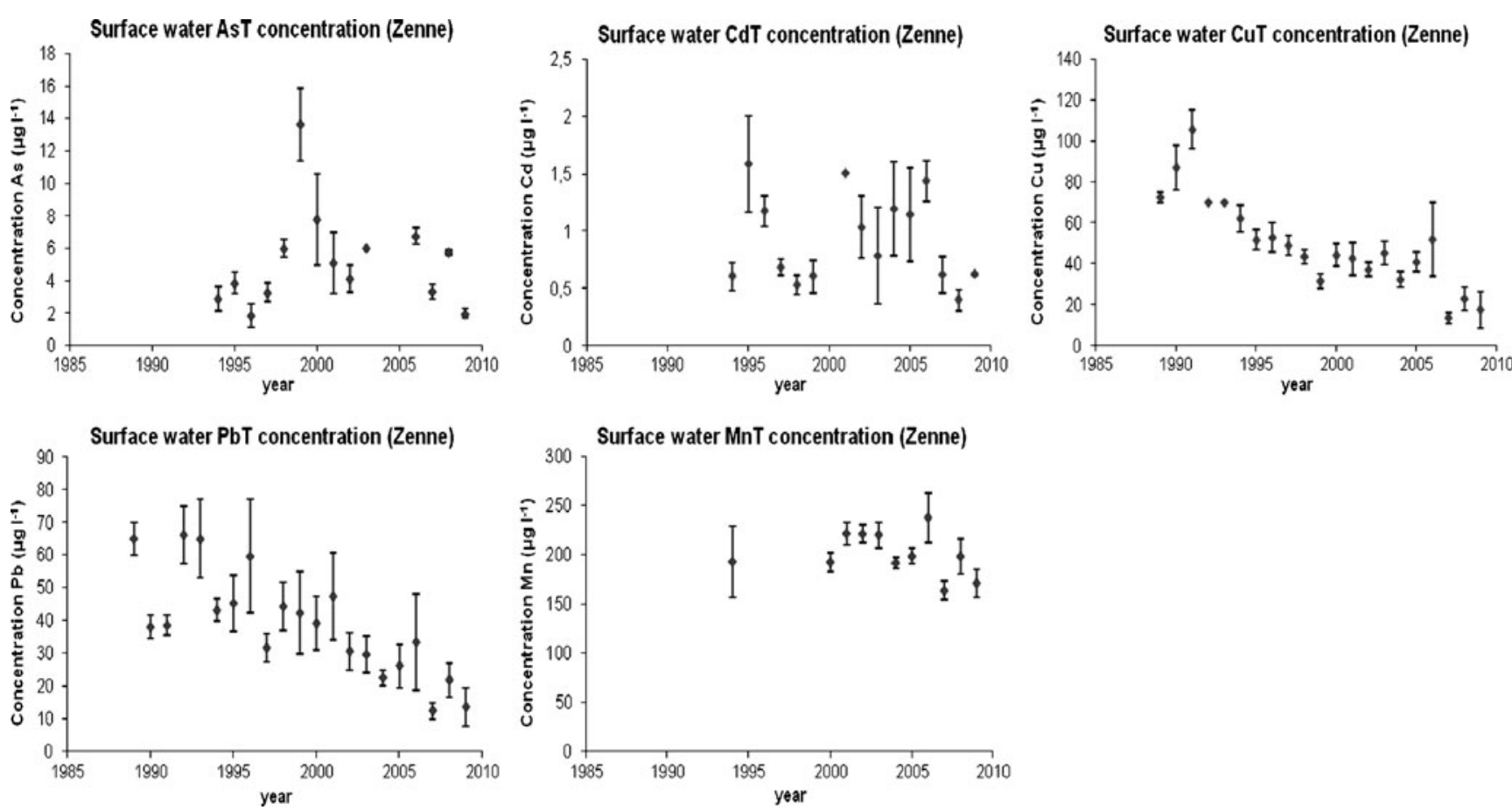

Fig. 7 Zenne surface water total metal concentrations (one sampling point). Measuring frequency differs between metals and years. Year mean ( $n$, between 1 and 24) values with standard error

(Simpson et al. 1998). This can be confirmed by the observed increase of the dissolved/total metal concentration ratio in the oxic-clear treatment compared to the anoxic treatment. Higher dissolved metal concentrations can indicate higher metal availability (Luoma and Rainbow 2008).

Together with the redox potential, the $\mathrm{pH}$ is one of the key factors controlling metal mobility (Gambrell 1994). Di Nanno et al. (2007) and Satawathananont et al. (1991) found a $\mathrm{pH}$ decrease caused by oxidation of metal sulfides. Since metals are more mobile under low $\mathrm{pH}$ conditions, this process can add to the mobilization effect of metal sulfide oxidation (Tack et al. 1996). This is not in accordance with the higher $\mathrm{pH}$ values observed in the oxic treatments of the experiment. Despite these higher $\mathrm{pH}$ values, metal mobility can be assumed to be higher in both oxic treatments since dissolved $\mathrm{As}, \mathrm{Cd}$, and $\mathrm{Cu}$ concentrations were higher.
Higher metal mobility in the sediment causing transfer to the surface water was also expected to have an effect on the pore water concentrations. Due to a high variability between replicas, no significant trends were observed. Except for Mn, where pore water concentrations exceeded considerably surface water concentrations, pore and surface water dissolved metal concentrations were more or less in the same order of magnitude. With differences in pore and surface water metal concentrations, fluxes of dissolved metals might be expected. Flux calculations, based on the experimental data and translated to the field situation, can give more insight in the importance of metal remobilization in natural systems. However, sediment-water fluxes are determined by adsorption, precipitation, and coprecipitation with organic matter, $\mathrm{Mn}$ and Fe oxyhydroxides, and metal sulfides. These processes show distinct variability with
Fig. 8 Zenne surface water dissolved metal concentrations (one sampling point). Measuring frequency differs between metals and years. Year mean ( $n$, between 2 and 24) values with standard error
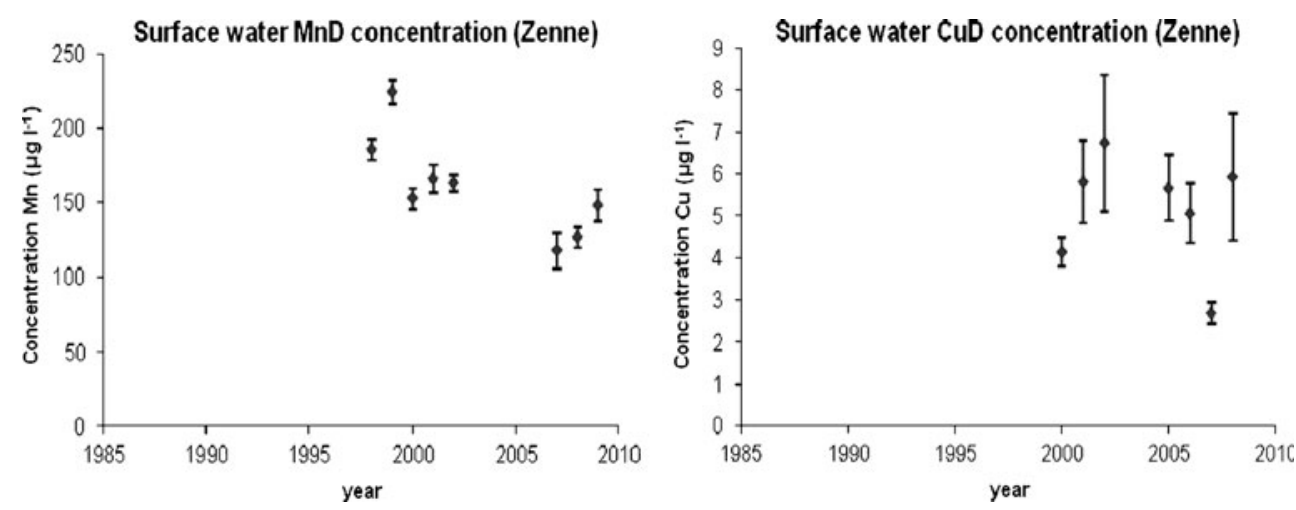
depth in the sediment, mainly driven by the redox potential (Boudreau 1999). As such, pore water concentrations from one specific depth in a sediment core (pore water was sampled at $2.5 \mathrm{~cm}$ depth) will not suffice to calculate fluxes through the sediment water interface. Flux calculations would require a full diagenetic model (Boudreau 1996, 1999) which would take re-reduction or re-oxidation, preventing the flux, into account.

No differences in surface water total metal concentrations between the anoxic and oxic-clear treatment were found. Total $\mathrm{As}, \mathrm{Cd}$, and $\mathrm{Cu}$ concentrations in these treatments were slightly higher than the dissolved fractions. The total $\mathrm{Pb}$ concentration, an element known to show even more than other metals high affinity for suspended matter (Luoma and Rainbow 2008), is at least by a factor 10 higher compared to the dissolved phase. All $\mathrm{Mn}$ found in the surface water of these treatments were dissolved. On the other hand, the oxic-turbid treatment resulted in a considerable increase in total metal concentrations. However, the increase was not significant. This can be attributed to the high variability observed in the surface water total metal concentrations. Most trace metals occurring in surface water are known to show a high affinity for particulate matter (Regnier and Wollast 1993). A positive, highly significant correlation between surface water total metal and suspended solid concentration in the experiment was found. The total metal concentration in the surface water depends on the amount of suspended sediments in the sample. Consequently, the high variability in suspended solid concentrations between treatments and replicas explains the total metal concentration variability.

Metal concentrations in suspended solids of the experiment were calculated and found to be in the same order of magnitude to sediment metal concentrations which indicates that the total metal concentration was determined by the amount of surface sediment in suspension. Suspended solid metal concentrations in the river Zenne were calculated and found to be roughly a factor 5 higher than if this were only sediments in suspension. Metals have a high affinity for fine-grained suspended solids and organic matter. These fractions are preferably transported in the water column while heavier particles will settle down.

Higher trace metal mobility subsequent to surface water aeration was observed in the experiment. Decades of anoxia and metal polluted sediments make the Zenne a feasible candidate for metal remobilization. Nevertheless, waste water treatment and hence surface water oxygen increase go together with a decrease in Zenne surface water total metal concentrations. The removal of the metal-rich suspended solids in the river Zenne by the waste water treatment process probably caused the removal of trace metals.
Dissolved $\mathrm{Cu}$ concentrations in the river Zenne are lower than the concentration in the oxic-clear treatment. Additionally, the dissolved $\mathrm{Cu}$ concentration and the dissolved/ total $\mathrm{Cu}$ ratio in the Zenne did not change clearly after the waste water treatment plant became operative. This can indicate that metal availability in the river will not alter drastically with waste water treatment. However, based on the scarce data on dissolved metal concentrations in the Zenne, we could not draw clear conclusions on a probable effect of aeration causing a higher dissolved metal fraction and hence a higher availability in the sediments or the water column.

\section{Conclusions}

Aeration of surface water resulted in metal sulfide oxidation in superficial sediments and suspended solids in the experiment. This caused higher dissolved surface water trace metal concentrations. Waste water treatment in the river Zenne resulted in an increase in surface water oxygen concentrations. However, a decrease of total metal surface water concentrations was observed subsequent to waste water treatment. From the results of this research, we can conclude that the gradual decrease in metal surface water concentration in the Zenne before the treatment started and the removal of suspended solid bound metals during the waste water treatment process could not be countered by an increase in metal flux from the sediment as observed in the experiment. Additionally, the limited results on dissolved metal concentrations indicated no noticeable change in metal availability following waste water treatment in the Zenne. Sediment metal release due to sulfide oxidation can be too slow to be observed in the field. A low residence time and high dilution can mask observations of metal remobilization in the field.

Acknowledgements We gratefully acknowledge The Flemish Environment Agency (VMM) for the field data of the river Zenne we have used. Johnny Teuchies was granted a PhD fellowship of the Research Foundation-Flanders (FWO). We would like to thank Dimitri Van Pelt and Joke Meynendonckx for their help with sampling and preparation of the experiment. We acknowledge Tom van der Spiet, Eva De Bruyn, Lieve Clement, and Kayawe Valentine Mubiana for the accurate analyses.

This study was performed within the project MODELKEY (contract no. 511237-GOCE). We gratefully acknowledge the financial support granted by the European Commission and W\&Z (Waterwegen en Zeekanaal NV, afdeling Zeeschelde).

This is publication 4912 of the NIOO-KNAW Netherlands Institute of Ecology.

Open Access This article is distributed under the terms of the Creative Commons Attribution Noncommercial License which permits any noncommercial use, distribution, and reproduction in any medium, provided the original author(s) and source are credited. 


\section{References}

Allen HE, Fu GM, Deng BL (1993) Analysis of acid-volatile sulphide (AVS) and simultaneously extracted metals (SEM) for the estimation of potential toxicity in aquatic sediments. Environ Toxicol Chem 12:1441-1502

Bose P, Sharma A (2002) Role of iron in controlling speciation and mobilization of arsenic in subsurface environment. Water Res 36:4916-4926

Boudreau BP (1996) Diagenetic models and their implementation. Modelling transport and reactions in aquatic sediments. Springer, New York

Boudreau BP (1999) Metals and models: diagenetic modelling in freshwater lacustrine sediments. J Paleolimnol 22:227-251

Cappuyns V, Swennen R, Devivier A (2006) Dredged river sediments: potential chemical time bombs? A case study. Water Air Soil Pollut 171:49-66

Di Nanno MP, Curutchet G, Ratto S (2007) Anaerobic sediment potential acidification and metal release risk assessment by chemical characterization and batch resuspension experiments. $\mathrm{J}$ Soils Sediments 7:187-194

Di Toro DM, Mahony JD, Hansen DJ, Scott KJ, Hicks MB, Mayr SM, Redmond MS (1990) Toxicity of cadmium in sediments: the role of acid volatile sulfide. Environ Toxicol Chem 9:1487-1502

Di Toro DM, Mahony JD, Hansen DJ, Scott KJ, Carlson AR, Ankley GT (1992) Acid volatile sulfide predicts the acute toxicity of cadmium and nickel in sediments. Environ Sci Technol 26:96101

Du Laing G, Rinklebe J, Vandecasteele B, Meers E, Tack FMG (2009) Trace metal behaviour in estuarine and riverine floodplain soils and sediments: a review. Sci Total Environ 407:3972-3985

Eggleton J, Thomas KV (2004) A review of factors affecting the release and bioavailability of contaminants during sediment disturbance events. Environ Int 30:973-980

Flemish Government Vlarebo (1996) Besluit van de Vlaamse regering van 5 maart 1996 houdende Vlaams regelement betreffende de bodemsanering. Belgische Staatsblad; 1996. 27 March (in Dutch)

Flemish Government Vlarem (2000) Besluit van de Vlaamse Regering van 1 juni 1995 houdende vaststelling van het Vlaamse reglement betreffende de milieuvergunning (Vlarem), zoals gewijzigd bij besluit van 17 juli 2000. Belgisch Staatsblad; 2000. 5 August (in Dutch)

Gambrell RP (1994) Trace and toxic metals in wetlands - a review. J Environ Qual 23:883-891

Hart BT (1982) Uptake of trace metals by sediments and suspended particulates: a review. Hydrobiologia 91:299-313

Hartley W, Dickinson NM (2010) Exposure of an anoxic and contaminated canal sediment: mobility of metal(loid)s. Environ Pollut 158:649-657
Hedge LH, Knott NA, Johnston EL (2009) Dredging related metal bioaccumulation in oysters. Mar Pollut Bull 58:832-840

Keimowitz AR, Zheng Y, Chillrud SN, Mailloux B, Jung HB, Stute M, Simpson HJ (2005) Arsenic redistribution between sediments and water near a highly contaminated source. Environ Sci Technol 39:8606-8613

Li L, Hall K, Yuan Y, Mattu G, McCallum D, Chen M (2009) Mobility and bioavailability of trace metals in the water-sediment system of the highly urbanized brunette watershed. Water Air Soil Pollut 197:249-266

Luoma SN, Rainbow PS (2008) Metal contamination in aquatic environments. Cambridge University Press, New York

Maddock J, Carvalho M, Santelli R, Machado W (2007) Contaminant metal behaviour during re-suspension of sulphidic estuarine sediments. Water Air Soil Pollut 181:193-200

Moore JN, Ficklin WH, Johns C (1988) Partitioning of arsenic and metals in reducing sulfidic sediments. Environ Sci Technol $22: 432-437$

Morse JW (1994) Interactions of trace metals with authigenic sulfide minerals: implications for their availability. Mar Chem 46:1-6

Morse JW, Rickard D (2004) Chemical dynamics of sedimentary acid volatile sulfide. Environ Sci Technol 38:131A-136A

Petersen W, Willer E, Willamowski C (1997) Remobilisation of trace elements from polluted anoxic sediments in oxic water. Water Air Soil Pollut 9:515-522

Peterson GS, Ankley GT, Lenonard EN (1996) Effect of bioturbation on metal-sulfide oxidation in surficial freshwater sediments. Environ Toxicol Chem 15:2147-2155

Regnier P, Wollast R (1993) Distribution of trace metals in suspended matter of the Scheldt estuary. Mar Chem 43:3-19

Satawathananont S, Patrick WH, Moore PA (1991) Effect of controlled redox conditions on metal solubility in acid sulfate soils. Plant Soil 133:281-290

Saulnier I, Mucci A (2000) Trace metal remobilization following the resuspension of estuarine sediments: Saguenay Fjord, Canada. App Geochem 15:191-210

Sharma VK, Sohn M (2009) Aquatic arsenic: toxicity, speciation, transformations, and remediation. Environ Int 35:743-759

Simpson SL, Apte SC, Batley GE (1998) Effect of short-term resuspension events on trace metal speciation in polluted anoxic sediments. Environ Sci Technol 32:620-625

Tack FM, Callewaert OWJJ, Verloo MG (1996) Metal solubility as a function of $\mathrm{pH}$ in contaminated, dredged sediment affected by oxidation. Environ Pollut 91:199-208

Van den Berg GA, Loch JPG, Van der Heijdt LM, Zwolsman JJG (1998) Mobilisation of heavy metals in contaminated sediments in the river Meuse, The Netherlands. Water Air Soil Pollut 116:567-586

Zhuang Y, Allen HE, Gongmin F (1994) Effect of aeration of sediment on cadmium binding. Environ Toxicol Chem 13:717-724 